\title{
Air Pollution Profiles and Health Risk Assessment of Ambient Volatile Organic Compounds above a Municipal Wastewater Treatment Plant, Taiwan
}

\author{
Dika Rahayu Widiana ${ }^{1,2}$, Ya-Fen Wang ${ }^{2 *}$, Sheng-Jie You ${ }^{2}$, Hsi-Hsien Yang ${ }^{3}$, Lin-Chi Wang ${ }^{4,5,6}$, \\ Jung-Hsuan Tsai ${ }^{2}$, Home-Ming Chen ${ }^{2,7}$ \\ ${ }^{1}$ Department of Civil Engineering, Chung Yuan Christian University, Taoyuan 32023, Taiwan \\ ${ }^{2}$ Department of Environmental Engineering, Chung Yuan Christian University, Taoyuan 32023, Taiwan \\ ${ }^{3}$ Department of Environmental Engineering and Management, Chaoyang University of Technology, Taichung 41349, \\ Taiwan \\ ${ }^{4}$ Department of Civil Engineering and Geomatics, Cheng Shiu University, Kaohsiung 83347, Taiwan \\ ${ }^{5}$ Center for Environmental Toxin and Emerging-Contaminant Research, Cheng Shiu University, Kaohsiung 83347, \\ Taiwan \\ ${ }^{6}$ Super Micro Mass Research and Technology Center, Cheng Shiu University, Kaohsiung 83347, Taiwan \\ ${ }^{7}$ Sewerage Systems Office, Public Works Department, Taipei City Government, Taipei 10376, Taiwan
}

\begin{abstract}
Municipal wastewater treatment processes have the function of removing harmful pollutants in the wastewater. However, there are probably several problems of air emissions related to these processes, especially for residents who live near a wastewater treatment plant. Volatile organic compounds exposure increases the risk of cancer. Thus, the health risk of residents to ambient volatile organic compounds exposure is essential to be conducted. One hundred and three volatile organic compounds (VOCs), total volatile organic compounds (TVOCs), and some prominent air pollutants $\left(\mathrm{CO}, \mathrm{CO}_{2}\right.$, $\mathrm{NH}_{3}, \mathrm{H}_{2} \mathrm{~S}, \mathrm{PM}_{1}, \mathrm{PM}_{2.5}, \mathrm{PM}_{7}, \mathrm{PM}_{10}$, TSP) were investigated at the surface of an underground wastewater treatment plant in Taipei City during four different seasons. Twenty four VOCs were identified, some of which were categorized as carcinogenic to humans (Group 1) and possibly carcinogenic to humans (Group 2B) according to the International Agency for Research on Cancer. The mean values of $\mathrm{CO}, \mathrm{CO}_{2}, \mathrm{PM}_{1}, \mathrm{PM}_{2.5}, \mathrm{PM}_{7}, \mathrm{PM}_{10}$ and TSP were found to be $0.64 \mathrm{ppm}$, $293.68 \mathrm{ppm}, 1.37 \mu \mathrm{g} \mathrm{m}^{-3}, 3.20 \mu \mathrm{g} \mathrm{m}^{-3}, 10.74 \mu \mathrm{g} \mathrm{m}^{-3}, 13.48 \mu \mathrm{g} \mathrm{m}^{-3}$, and $16.90 \mu \mathrm{g} \mathrm{m}^{-3}$, respectively. $\mathrm{NH}_{3}$ and $\mathrm{H}_{2} \mathrm{~S}$ were not detected in the present study. The health risk for residents was estimated following the method from United States Environmental Protection Agency (U.S. EPA). The cumulative of carcinogenic risk was $3.48 \times 10^{-5}$ and categorized as a possible risk. In addition, the result was also possibly affected by traffic nearby. The magnitude for non-carcinogenic risk index was less than 1.
\end{abstract}

Keywords: Air pollutant; Wastewater treatment plant; Volatile organic compound; Cancer risk.

\section{INTRODUCTION}

Various types of contaminants are released into the atmosphere during the process of wastewater treatment and pollute the environment in numerous ways. There are odor problems as well as production of greenhouse gases during wastewater treatment (Hua et al., 2018; Rai, 2018). Volatile organic compounds (VOCs) and other gaseous pollutants, such as methane, ammonia, hydrogen sulphide and particulate matter were detected in air surrounding the wastewater

\footnotetext{
* Corresponding author.

Tel.: +886-32654912; Fax: +886-3-265-4949

E-mail address: yfwang@cycu.edu.tw
}

treatment plant (Hamoda, 2006; Widiana et al., 2017).

Aeration and biological treatment have influences on the fates of aromatic volatile organic compounds (VOCs) in wastewater treatment processes (Chen et al., 2013). VOCs in ambient air are an increasing concern because many of them have been identified to be human carcinogens (Chen et al., 2016). Ammonia released into the atmosphere can constitute a source of olfactory nuisance (Chou and Wang, 2007). Hydrogen sulfide has peculiar smell and is also toxic to humans and environment (Liu and Wang, 2017). Particulate matter may affect the human respiratory, cardiovascular, and nervous system (Fang et al., 2010; Haynes et al., 2012; Wu et al., 2013; Abe et al., 2018; Zhang et al., 2018).

Aeration process is one of the sources of particulate matter and $\mathrm{NH}_{3}$ in wastewater treatment plant (Upadhyay 
et al., 2012). $\mathrm{CO}_{2}$ is produced from biological wastewater treatment process and is defined as biogenic (Vijayan et al., 2017). Moreover, other sources of ambient particulate matter was motor vehicle exhaust (Kumar and Yadav, 2016); therefore, if the location of the wastewater treatment plant is near the road, particulate matter will most likely be detected in its air surrounding. Solvent usages and paint applications are also sources of volatile organic compounds in municipal sewer and wastewater treatment plant (Huang et al., 2012; Widiana et al., 2017). While sources of ambient volatile organic compounds are mobile exhaust, stationary pollution from chemical or oil refinery plants, and natural emissions of animals and plants (Wang et al., 2016b).

Municipal wastewater treatment plant A is the largest secondary treatment plant in Taiwan with a capacity of $500,000 \mathrm{~m}^{3}$ per day (TCG, 2017). It treats sewage from Taipei City household connections and interception stations. Most studies of air quality in wastewater treatment plants have focused mainly on the characteristics of microbial aerosols (Li et al., 2013; Dehghani et al., 2018). In the present study, the seasonal $\mathrm{CO}, \mathrm{CO}_{2}, \mathrm{PM}_{1}, \mathrm{PM}_{2.5}, \mathrm{PM}_{7}$, $\mathrm{PM}_{10}$, TSP, $\mathrm{NH}_{3}, \mathrm{H}_{2} \mathrm{~S}$, TVOC and VOCs concentrations in wastewater treatment plant $\mathrm{A}$ in Taipei City were measured outdoor. The TVOC seasonal concentration distributions were plotted using Surfer 10 program. This study was conducted on the surface of an underground municipal wastewater treatment plant A to investigate the air pollution profiles and the exposure level of residents nearby the wastewater treatment plant to volatile organic compounds. In addition, the health risks of ambient volatile organic compounds exposure for residents nearby the wastewater treatment plant were also estimated following the method from United States Environmental Protection Agency (U.S. EPA). Our findings provide a basis for improving the air quality in order to control the health risk of residents. The study of health risk assessment for residents nearby wastewater treatment plants is limited by the fact that few studies have done a similar investigation.

\section{DATA AND METHODS}

\section{Sample Collection}

All sampling collection was in the recreational sport park that was built on Municipal wastewater treatment plant A. The whole park was divided into four areas (A, B, $\mathrm{C}$, and D area), and from each area, samples were taken at several points. The total sampling points for all areas were 30 (Fig. 1), while VOCs samples were taken at only one point for each of the four areas. The sampling was set at $1.2 \mathrm{~m}$ from the ground. Sampling periods were chosen in February 2016 (winter), May 2016 (spring), August 2016 (summer), and November 2016 (autumn). Samples were taken once in every season during the day of 08:00 am to 10:00 am.

\section{Chemical Analysis}

Sampling and its analysis were described in detail in a previous study (Widiana et al., 2017). VOCs samples were collected using passive flow control canisters with volume $6 \mathrm{~L}$ and flow rate was fixed at $40 \mathrm{~mL} \mathrm{~min}^{-1}$. All canisters were cleaned and vacuumed using humid $\mathrm{N}_{2}$ pure gas to guarantee their vacuum quality before sampling. This study adopted the United States Environmental Protection Agency Method TO-15 and Photochemical Assessment Monitoring System for quality control during the sampling, preservation,

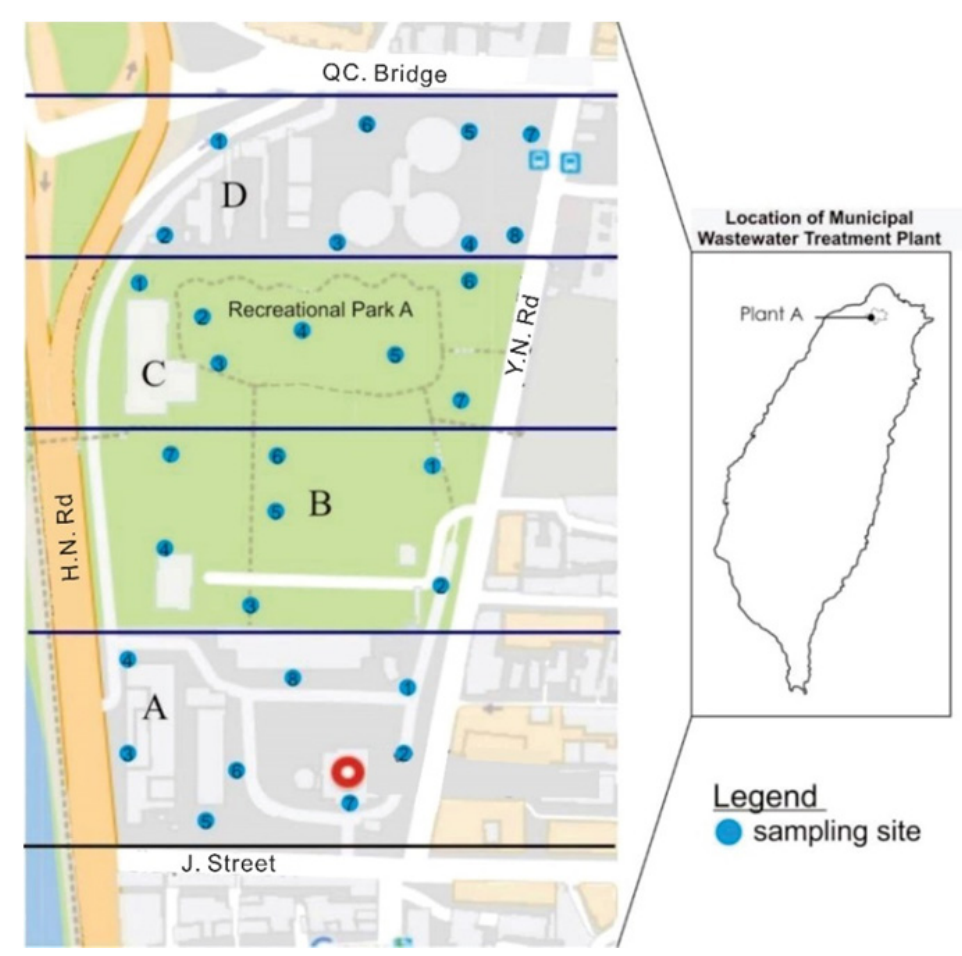

Fig. 1. Location of the sampling site. 
transportation, and analysis. Air samples were then analyzed using a gas chromatograph (GC, Agilent 6890N) and a mass spectrometer (MS, Agilent 5973MSD). The GC oven temperature was set at $32^{\circ} \mathrm{C}$, increased to $200^{\circ} \mathrm{C}$, and kept constant for $3 \mathrm{~min}$. Several standard gases were used to calibrate VOCs (Ou-Yang et al., 2017). For each compound, calibration was done and a good linear fit was observed with $\mathrm{R}^{2}>0.99$.

Sampling of $\mathrm{CO}$ and $\mathrm{CO}_{2}$ was done using the instrument Q-TRAKTM Indoor Air Quality Monitor 7575 (TSI, Shoreview, United States). Calibration was done in the field. The appropriate detachable probes were attached to the instrument before field calibration, except for pressure and barometric pressure calibration. Particulate matter (PM) was measured using the instrument Met One Aerocet 531 particle profilers (Met One Instruments, Inc. Grants Pass, Oregon). The Aerocet 531 was calibrated using NIST (National Institute of Standard and Technology) traceable polystyrene. Real-time TVOC was measured using a portable PpbRAE 3000, photo-ionization detector (PID) having a $10.6 \mathrm{eV}$ photoionization lamp detector (RAE System Inc., San Jose, CA). The TVOC monitor was calibrated using $100 \mathrm{ppm}$ isobutylene and zero air following the manufacturer's recommendations (Singh et $a l ., 2016)$. The real ambient TVOC concentrations mapping were obtained using Surfer 10, which was developed by Golden Software Inc., USA. $\mathrm{NH}_{3}$ and $\mathrm{H}_{2} \mathrm{~S}$ were measured using MultiRAE Lite PGM-620X (RAE Systems, San Jose, USA). Bump testing and gas detector calibration equipment were used regularly in accordance with OSHA guidelines. This is because bump testing equipment helps to ensure all the sensors are working properly to detect toxic gases.

\section{Health Risk Assessment for the Residents}

Health risk assessment focused on the chronic exposure to VOCs that are carcinogenic or non-carcinogenic, rather than acute exposure (He et al., 2015). The lifetime cancer risk (LCR) is calculated using the equation (Singh et al., 2016):

$$
\mathrm{LCR}=\mathrm{CDI} \times \mathrm{CSF}
$$

Non-carcinogenic risk is characterized in terms of a hazard index (HI) which is defined as the ratio of chronic daily intake to the reference dose.

$$
H I=\frac{C D I}{R f D}
$$

While chronic daily intake (CDI) is calculated using the equation:

$$
C D I=\frac{C \times C F \times I R \times E F \times E D}{B W \times A T}
$$

The description of the variables used is summarized in Table 3. CSF and RfD were obtained by back-calculating the published unit risk and reference concentration values from U.S. EPA (U.S. EPA, 2017) based on the standard adult inhalation rate $\left(20 \mathrm{~m}^{3} \mathrm{day}^{-1}\right)$ and lifetime (70 years) (Sofuoglu et al., 2011), except for isoprene (Haney et al., 2015). Table 4 lists the CSF and RfD.

\section{RESULTS AND DISCUSSIONS}

\section{Level of Air Pollutants}

Table 1 shows $\mathrm{CO}, \mathrm{CO}_{2}, \mathrm{PM}, \mathrm{TSP}, \mathrm{H}_{2} \mathrm{~S}$, and $\mathrm{NH}_{3}$ concentrations. The mean concentration of $\mathrm{CO}$ and $\mathrm{CO}_{2}$ for four seasons were in the range $0.17-0.99 \mathrm{ppm}$ and 259 $310 \mathrm{ppm}$, respectively. The mean concentration of $\mathrm{PM}_{1}$, $\mathrm{PM}_{2.5}, \mathrm{PM}_{7}, \mathrm{PM}_{10}$ and TSP for four seasons were in the range $0.53-1.67 \mu \mathrm{g} \mathrm{m}^{-3}, 2.10-4.97 \mu \mathrm{g} \mathrm{m}^{-3}, 7.43-17.9 \mu \mathrm{g} \mathrm{m}^{-3}$, 9.33-22.5 $\mu \mathrm{g} \mathrm{m}^{-3}$, and $11.1-29.0 \mu \mathrm{g} \mathrm{m}^{-3}$, respectively. In the present study, $\mathrm{H}_{2} \mathrm{~S}$ and $\mathrm{NH}_{3}$ were not detected.

The results in the present study were close to previous study (Widiana et al., 2017), except for $\mathrm{PM}_{2.5}, \mathrm{PM}_{7}, \mathrm{PM}_{10}$ and TSP which were lower. The previous study show the mean concentration of $\mathrm{CO}$ and $\mathrm{CO}_{2}$ for four seasons in the ambient air were in the range $0-1.45 \mathrm{ppm}$ and 286$322 \mathrm{ppm}$, respectively. The mean concentration of $\mathrm{PM}_{1}$, $\mathrm{PM}_{2.5}, \mathrm{PM}_{7}, \mathrm{PM}_{10}$ and TSP for four seasons were in the range $0-2.09 \mu \mathrm{g} \mathrm{m}^{-3}, 2-6.64 \mu \mathrm{g} \mathrm{m}^{-3}, 8.55-22.6 \mu \mathrm{g} \mathrm{m}^{-3}$, $10.2-27.1 \mu \mathrm{g} \mathrm{m}^{-3}$, and $12-30.6 \mu \mathrm{g} \mathrm{m}^{-3}$, respectively. $\mathrm{H}_{2} \mathrm{~S}$ and $\mathrm{NH}_{3}$ were also not detected.

Hamoda (2006) investigated the presence of VOCs and other gaseous pollutants such as methane, ammonia, and

\begin{tabular}{|c|c|c|c|c|c|c|c|c|c|c|c|c|c|c|c|}
\hline \multirow{2}{*}{ Parameter } & \multicolumn{3}{|c|}{ All } & \multicolumn{3}{|c|}{ Winter } & \multicolumn{3}{|c|}{ Spring } & \multicolumn{3}{|c|}{ Summer } & \multicolumn{3}{|c|}{ Autumn } \\
\hline & $\mathrm{n}$ & Mean & SD & $\mathrm{n}$ & Mean & $\mathrm{SD}$ & $\mathrm{n}$ & Mean & SD & $\mathrm{n}$ & Mean & SD & $\mathrm{n}$ & Mean & $\mathrm{SD}$ \\
\hline $\mathrm{CO}(\mathrm{ppm})$ & 120 & 0.64 & 0.40 & 30 & 0.17 & 0.11 & 30 & 0.99 & 0.22 & 30 & 0.95 & 0.21 & 30 & 0.44 & 0.26 \\
\hline $\mathrm{CO}_{2}(\mathrm{ppm})$ & 120 & 293 & 33.5 & 30 & 259 & 15.0 & 30 & 310 & 33.2 & 30 & 304 & 34.3 & 30 & 298 & 21.4 \\
\hline $\mathrm{PM}_{1}\left(\mu \mathrm{g} \mathrm{m}^{-3}\right)$ & 65 & 1.37 & 0.60 & 4 & 1.67 & 1.21 & 30 & 33.4 & 0.53 & 2 & 1 & 0 & 29 & 1 & 0 \\
\hline $\mathrm{PM}_{2.5}\left(\mu \mathrm{g} \mathrm{m}^{-3}\right)$ & 118 & 3.20 & 1.60 & 28 & 3.39 & 0.88 & 30 & 3.30 & 0.70 & 30 & 2.10 & 0.84 & 30 & 4.97 & 1.81 \\
\hline $\mathrm{PM}_{7}\left(\mu \mathrm{g} \mathrm{m}^{-3}\right)$ & 118 & 10.7 & 4.97 & 28 & 9.39 & 2.90 & 30 & 8.10 & 1.90 & 30 & 7.43 & 2.28 & 30 & 17.9 & 3.06 \\
\hline $\mathrm{PM}_{10}\left(\mu \mathrm{g} \mathrm{m}^{-3}\right)$ & 118 & 13.5 & 6.45 & 28 & 12.4 & 3.66 & 30 & 9.67 & 2.15 & 30 & 9.33 & 3.54 & 30 & 22.5 & 4.49 \\
\hline $\operatorname{TSP}\left(\mu \mathrm{g} \mathrm{m}^{-3}\right)$ & 118 & 16.9 & 10.1 & 28 & 15.4 & 5.09 & 30 & 11.1 & 2.42 & 30 & 12.0 & 5.97 & 30 & 29.0 & 11.6 \\
\hline $\mathrm{NH}_{3}(\mathrm{ppm})$ & 0 & ND & - & 0 & ND & - & 0 & ND & - & 0 & - & ND & 0 & ND & - \\
\hline $\mathrm{H}_{2} \mathrm{~S}(\mathrm{ppm})$ & 0 & ND & - & 0 & ND & - & 0 & ND & - & 0 & - & ND & 0 & ND & - \\
\hline
\end{tabular}
hydrogen sulfide in air surrounding municipal wastewater

Table 1. $\mathrm{CO}, \mathrm{CO}_{2}$, PM, TSP, $\mathrm{H}_{2} \mathrm{~S}$, and $\mathrm{NH}_{3}$ concentrations in municipal wastewater treatment plant A.

ND: not detected; n: number of samples; SD: standard deviation. 
treatment plant in the State of Kuwait. In some cases the concentration exceeded the air quality standard. Lee et al. (2007) investigated the air quality of four wastewater treatment plants in Iowa, USA by monitoring the levels of hydrogen sulfide. The result show that the geometric means of hydrogen sulfide was less than $1 \mathrm{ppm}$.

\section{Level of TVOCs}

The locations of potential source of VOCs were identified using surfer program to plot seasonal concentration distributions. The concentration distribution of TVOCs for every seasons can be seen in Fig. 2. From Fig. 2, it can be seen that higher TVOC concentrations for each of the four seasons were distributed over the Sampling area A, which was surrounded by Y. N. Road, J. Street, and H. N. Road in the east, south, and west side, respectively. On the sampling area A, a car park can be found.

\section{VOCs Characteristics}

Benzene and toluene ratio (T/B) has been widely used as a simple method for evaluating the vehicle exhaust contribution to aromatics (Nelson and Quigley, 1984). T/B less than 2.0 indicated that aromatics were significantly influenced by vehicle emissions (Wang et al., 2016a).
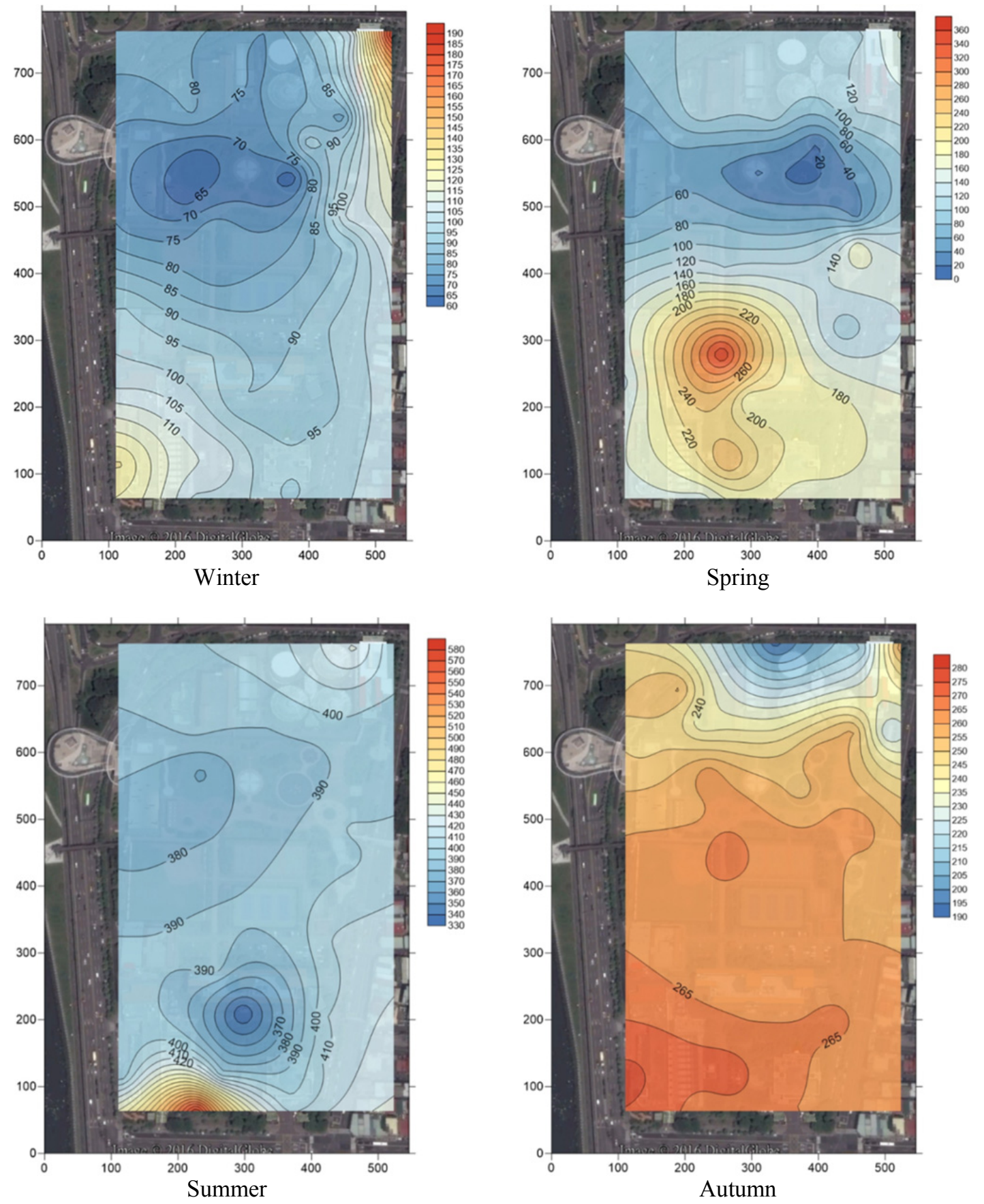

Fig. 2. Concentration distributions of TVOC for four seasons. 
From Table 2, it can be seen that the average concentrations of toluene and benzene were $4.64 \mu \mathrm{g} \mathrm{m}^{-3}$ and $10.4 \mu \mathrm{g} \mathrm{m}^{-3}$, respectively, therefore the $\mathrm{T} / \mathrm{B}$ ratio obtained in the present study was 0.45 , traffic influenced more. Ethanol yielded the highest mean concentration of VOCs followed by acetone and isopropyl alcohol.

Several factors that affect the seasonal variation of VOCs in the atmosphere were: first, the photochemical removal primarily by the hydroxyl $(\mathrm{OH})$ radical in warmer seasons which result in higher chemical removal reaction rates than in cooler seasons because of more sunlight and high temperatures. Therefore the chemical removal of VOCs is faster in warmer seasons than in cooler seasons (Ho et al., 2004). Second, the dilution as a result of atmospheric mixing. The dilution of airborne pollutants from ground water emissions in warmer seasons is stronger than in cooler system because the mixing layer is much higher in warmer seasons than in cooler seasons. Third, the principal source of VOCs, since the site is a recreational sports park, the principal source of VOCs will change with the tourism seasonal variations significantly.

Based on Table 2, the highest total of the VOCs appeared in spring because spring is a favorable season for tourism. Photochemical removal and dilution are weak because of the lower temperatures. Therefore, VOCs accumulates and the highest value appears in this season. Emission sources present in autumn are lower than those in summer and the effects of photochemical removal and dilution are still strong. Therefore, the lowest values of VOCs appeared in autumn (Zhang et al., 2014). As shown in Fig. 3, the highest concentration and contribution of VOC groups was alkane then followed by alcohol and aromatics with concentration $50.7 \mu \mathrm{g} \mathrm{m}^{-3}, 47.6 \mu \mathrm{g} \mathrm{m}^{-3}$ and $34.9 \mu \mathrm{g} \mathrm{m}^{-3}$, respectively.

\section{Health Risk Assessment}

In the present study, for all detected VOCs, only eight quantified VOCs were estimated according to the inhalation unit risk and reference dose values for carcinogenic and non-carcinogenic effects. Table 4 shows the lifetime cancer risk and hazard index. The lifetime cancer risk of the compounds determined by the US EPA was less than $10^{-6}$ and categorized as negligible or insignificant risk. The compounds with lifetime cancer risk less than $10^{-5}$ and higher than $10^{-6}$ were categorized as a possible risk, lifetime cancer risk less than $10^{-4}$ and higher $10^{-5}$ as a probable risk, and lifetime cancer risk higher than $10^{-4}$ as a definite risk (Sexton et al., 2007).

According to the International Agency for Research on Cancer (IARC), three of the investigated VOCs are classified into two carcinogenic categories: group 1 (the agents is carcinogenic to human such as benzene) and group 2B (the agents is possibly carcinogenic to humans such as isoprene and methylene chloride). From Table 4 one compound (benzene) was regarded as possible risk and two other compounds (isoprene and methylene chloride)

Table 2. VOCs concentrations $\left(\mu \mathrm{g} \mathrm{m}^{-3}\right)$ in municipal wastewater treatment plant A.

\begin{tabular}{|c|c|c|c|c|c|c|c|c|c|c|c|c|c|c|c|}
\hline \multirow{2}{*}{ Compounds } & \multicolumn{3}{|c|}{ All } & \multicolumn{3}{|c|}{ Winter } & \multicolumn{3}{|c|}{ Spring } & \multicolumn{3}{|c|}{ Summer } & \multicolumn{3}{|c|}{ Autumn } \\
\hline & $\mathrm{n}$ & Mean & $\begin{array}{l}\mathrm{SD} \\
\end{array}$ & $\mathrm{n}$ & Mean & SD & $\mathrm{n}$ & Mean & SD & $\mathrm{n}$ & Mean & SD & $\mathrm{n}$ & Mean & $\mathrm{SD}$ \\
\hline Isobutane & 7 & 6.95 & 3.40 & 3 & 5.07 & 3.50 & 1 & 4.14 & 0 & 1 & 10.3 & 0 & 2 & 9.50 & 1.43 \\
\hline n-Butane & 5 & 13.6 & 4.22 & 1 & 9.92 & 0 & 1 & 17.4 & 0 & 1 & 18.7 & 0 & 2 & 10.9 & 1.60 \\
\hline Isopentane & 16 & 12.9 & 7.16 & 4 & 11.3 & 5.96 & 4 & 10.3 & 9.13 & 4 & 14.2 & 7.51 & 4 & 15.9 & 7.41 \\
\hline n-Pentane & 5 & 3.87 & 1.66 & 2 & 2.91 & 1.56 & 2 & 4.10 & 2.13 & 1 & 5.34 & 0 & - & ND & - \\
\hline 2-Methylpentane & 4 & 5.24 & 0.40 & 3 & 5.43 & 0.18 & - & ND & - & - & ND & - & 1 & 4.69 & 0 \\
\hline 2-Methylhexane & 1 & 5.37 & 0 & 1 & 5.37 & 0 & - & ND & - & - & ND & - & - & ND & - \\
\hline n-Hexane & 1 & 2.78 & 0 & 1 & 2.78 & 0 & - & ND & - & - & ND & - & - & ND & - \\
\hline Benzene & 4 & 10.4 & 13.50 & 4 & 10.4 & 13.50 & - & ND & - & - & ND & - & - & ND & - \\
\hline Toluene & 12 & 4.64 & 4.12 & 4 & 4.29 & 3.26 & 4 & 7.36 & 5.65 & 1 & 4.41 & 0 & 3 & 1.56 & 0.44 \\
\hline m-Xylene & 1 & 7.03 & 0 & 1 & 7.03 & 0 & - & ND & - & - & ND & - & - & ND & - \\
\hline 1,2,4-Trimethylbenzene & 1 & 12.8 & 0 & 1 & 12.83 & 0 & - & ND & - & - & ND & - & - & ND & - \\
\hline 1-Hexene & 1 & 5.4 & 0 & - & ND & - & 1 & ND & - & 1 & 5.40 & 0 & - & ND & - \\
\hline 1-Butene & 1 & 7.09 & 0 & - & ND & - & - & ND & - & - & ND & - & 1 & 7.09 & 0 \\
\hline Isoprene & 3 & 4.46 & 1.40 & - & ND & - & 0 & ND & - & 3 & 4.46 & 1.40 & - & ND & - \\
\hline Methyl Ethyl Ketone & 1 & 13.1 & 0 & - & ND & - & - & 13.1 & 0 & - & ND & - & - & ND & - \\
\hline Ethyl Acetate & 1 & 13.9 & 0 & - & ND & - & - & 13.9 & 0 & - & ND & - & - & ND & - \\
\hline Isopropyl Alcohol & 7 & 15.5 & 7.09 & 4 & 12.9 & 3.24 & - & 30.7 & 0 & - & ND & - & 2 & 13.2 & 1.72 \\
\hline Ethanol & 16 & 32.0 & 19.33 & 4 & 22.6 & 9.64 & 4 & 27.0 & 22.6 & 4 & 34.5 & 13.20 & 4 & 44.0 & 27.2 \\
\hline Acetone & 16 & 17.1 & 7.02 & 4 & 25.1 & 8.00 & 4 & 11.4 & 4.23 & 4 & 17.6 & 4.64 & 4 & 14.3 & 1.88 \\
\hline Methylene Chloride & 5 & 5.34 & 2.60 & 4 & 4.96 & 2.84 & 1 & ND & - & 1 & 6.88 & 0 & - & ND & - \\
\hline Freon-12 & 10 & 5.98 & 1.57 & - & ND & - & 4 & 5.60 & 0.95 & 4 & 6.49 & 2.42 & 2 & 5.71 & 0.03 \\
\hline Freon-11 & 15 & 5.51 & 1.44 & 4 & 4.17 & 0.12 & 4 & 4.75 & 1.09 & 4 & 6.64 & 1.36 & 3 & 6.78 & 0.32 \\
\hline Freon-113 & 2 & 5.63 & 0.16 & - & ND & - & 1 & 5.52 & 0 & 1 & 5.75 & 0 & - & ND & - \\
\hline Freon-114 & 1 & 8.04 & 0 & - & ND & 3.50 & - & 8.04 & - & 1 & ND & - & - & ND & 1.43 \\
\hline Total & & 225 & & & 147 & & & 163 & & & 141 & & & 134 & \\
\hline
\end{tabular}

ND: not detected; n: number of samples; SD: standard deviation. 
(a)

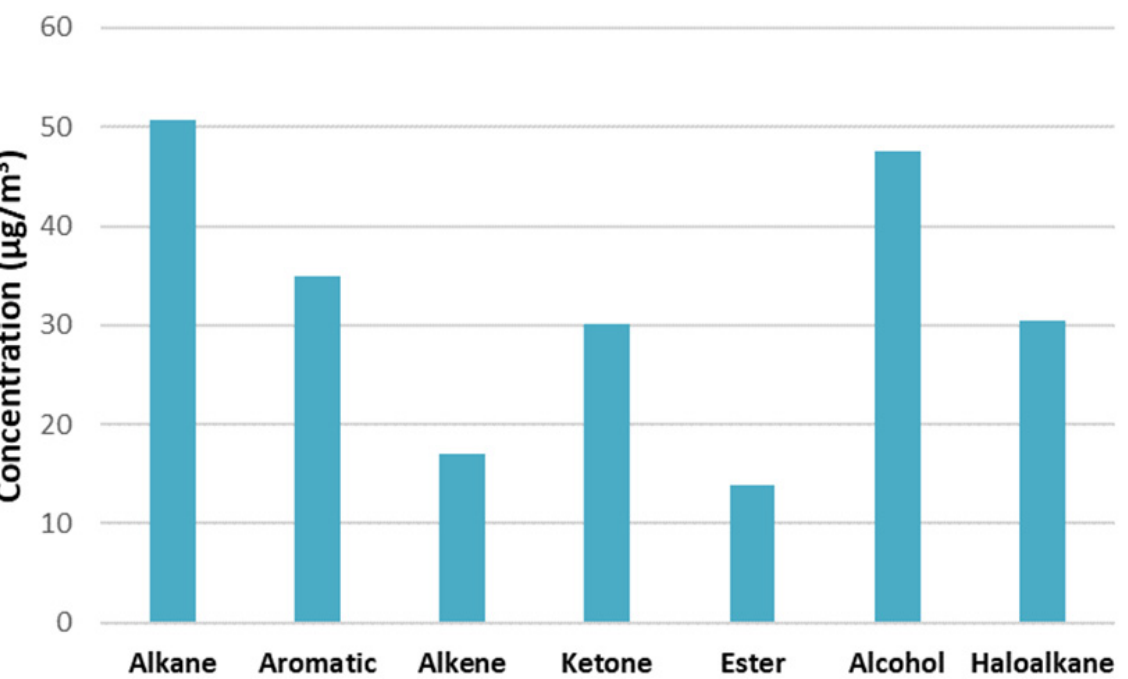

(b)

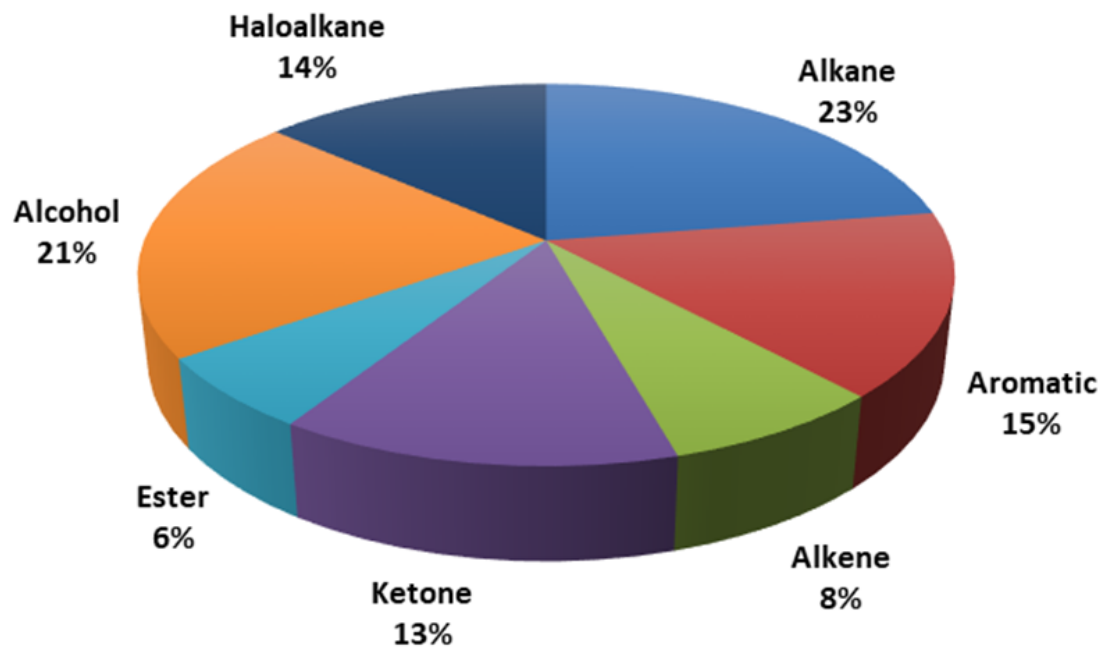

Fig. 3. (a) Concentration and (b) contribution of seven groups of VOCs.

were regarded as negligible or insignificant risk, and the cumulative of LCR was categorized as possible risk. Therefore, the provision of air pollution control is required to decrease the level of air pollutants. The identification of the air pollutant sources is the initial step in order to select the technology of air pollution control.

For the non-carcinogenic risk, HI greater than 1, the compound concentrations were considered to be above the level of concern (Ramírez et al., 2012). Otherwise, it is assumed that the risk is at acceptable level (Biesiada, 2001). Nevertheless, for HI greater than 0.1 and lower than 1 , the compounds were considered to be a potential risk to the residents health (McCarthy et al., 2009). Table 4 shows the highest risk for non-carcinogenic originated from 1,2,4-trimethylbenzene. However, the cumulative of noncarcinogenic risk was less than 1 and considered unlikely to affect the residents.

One factor that affects the uncertainty of health risk assessment is VOCs concentration. However, the uncertainty was not analyzed in the present study due to the limitation in sampling size (Table 2). When the number of samples of
VOCs is limited, then the distribution of VOCs concentration can not be accurately showed, which makes it difficult analyze the uncertainty. In future studies, the accuracy of the health risk assessment can be improved by considering a large size of samples.

\section{CONCLUSIONS}

Twenty four VOCs species, TVOCs, and some prominent air pollutants $\left(\mathrm{CO}, \mathrm{CO}_{2}, \mathrm{NH}_{3}, \mathrm{H}_{2} \mathrm{~S}, \mathrm{PM}_{1}, \mathrm{PM}_{2.5}, \mathrm{PM}_{7}\right.$, $\mathrm{PM}_{10}$, TSP) were identified from municipal wastewater treatment plant A. Some VOCs were categorized as carcinogenic to humans (Group 1) and possibly carcinogenic to humans (Group 2B) according to the IARC. According to the results of this study, higher concentrations of TVOCs were in the sampling area A which was surrounded by three streets in the west, south, and east side. The carcinogenic risk for the residents was categorized as possible risk with value $3.48 \times 10^{-5}$. In addition, the hazard index value was $6.47 \times 10^{-4}$ and considered unlikely to affect the residents. 
Table 3. The exposure assessment factors.

\begin{tabular}{|c|c|c|c|}
\hline Variable & Description & Value & Unit \\
\hline $\mathrm{C}$ & Concentration & & $\mu \mathrm{g} \mathrm{m}^{-3}$ \\
\hline $\mathrm{CF}$ & Conversion Factor & $1000^{-1}$ & $\mathrm{mg} \mu \mathrm{g}^{-1}$ \\
\hline $\mathrm{IR}^{*}$ & Inhalation Rate & 20 & $m^{3}$ day $^{-1}$ \\
\hline EF & Exposure Frequency & 365 & day year ${ }^{-1}$ \\
\hline ED & Exposure Duration & 30 & year \\
\hline $\mathrm{BW}^{*}$ & Body Weight & 70 & $\mathrm{~kg}$ \\
\hline \multirow[t]{3}{*}{ AT } & Average Lifetime & & day \\
\hline & - Carcinogenic & 25550 & \\
\hline & - Non-carcinogenic & $365 \times \mathrm{ED}$ & \\
\hline CSF & Cancer Slope Factors & & $\left(\mathrm{kg}-\right.$ day $\left.\mathrm{mg}^{-1}\right)$ \\
\hline RfD & Reference Dose & & $\left(\text { kg-day mg }{ }^{-1}\right)^{-1}$ \\
\hline
\end{tabular}

Table 4. Carcinogenic (LCR) and non-carcinogenic risk (HI) of VOCs

\begin{tabular}{|c|c|c|c|c|c|c|}
\hline \multirow{2}{*}{ Compounds } & \multirow{2}{*}{ CSF } & \multirow{2}{*}{ RfD } & \multicolumn{2}{|c|}{ Chronic Daily Intake } & \multirow{2}{*}{$\begin{array}{l}\text { Lifetime Cancer } \\
\text { Risk }\end{array}$} & \multirow{2}{*}{$\begin{array}{l}\text { Hazard } \\
\text { Index }\end{array}$} \\
\hline & & & Carcinogenic & Non-carcinogenic & & \\
\hline n-Hexane ${ }^{1}$ & - & 200 & - & $7.96 \times 10^{-4}$ & - & $3.98 \times 10^{-6}$ \\
\hline Benzene $^{1}$ & 0.027 & 8.57 & $1.27 \times 10^{-3}$ & $2.97 \times 10^{-3}$ & $3.48 \times 10^{-5}$ & $3.47 \times 10^{-4}$ \\
\hline Toluene $^{1}$ & - & 1428 & - & $1.34 \times 10^{-3}$ & - & $9.28 \times 10^{-7}$ \\
\hline m-Xylene ${ }^{1}$ & - & 28.6 & - & $2.01 \times 10^{-3}$ & - & $7.03 \times 10^{-5}$ \\
\hline $1,2,4$-Trimethylbenzene ${ }^{1}$ & - & 17.1 & - & $3.68 \times 10^{-3}$ & - & $2.14 \times 10^{-4}$ \\
\hline Isoprene $^{2}$ & $7.7 \times 10^{-5}$ & - & $5.46 \times 10^{-4}$ & - & $4.20 \times 10^{-8}$ & - \\
\hline Methyl Ethyl Ketone ${ }^{1}$ & - & 1429 & - & $3.74 \times 10^{-3}$ & - & $2.62 \times 10^{-6}$ \\
\hline Methylene Chloride $^{1}$ & $3.5 \times 10^{-5}$ & 171 & $6.54 \times 10^{-4}$ & $1.53 \times 10^{-3}$ & $2.29 \times 10^{-8}$ & $8.90 \times 10^{-6}$ \\
\hline Total & & & & & $3.48 \times 10^{-5}$ & $6.47 \times 10^{-4}$ \\
\hline
\end{tabular}

\section{ACKNOLEDGEMENTS}

The author thank to Chung Yuan Christian University for the support of this work

\section{REFERENCES}

Abe, K.C., Santos, G.M.S.d., Coêlho, M.d.S.Z.S. and Miraglia, S.G.E.K. (2018). $\mathrm{PM}_{10}$ exposure and cardiorespiratory mortality - estimating the effects and economic losses in São Paulo, Brazil. Aerosol Air Qual. Res. 18: 3127-3133.

Biesiada, M. (2001). Simulations in health risk assessment. Int. J. Occup. Environ. Health 14: 397-402.

Chen, M.J., Lin, C.H., Lai, C.H., Cheng, L.H., Yang, Y.H., Huang, L.J., Yeh, S.H. and Hsu, H.T. (2016). Excess lifetime cancer risk assessment of volatile organic compounds emitted from a petrochemical industrial complex. Aerosol Air Qual. Res. 16: 1954-1966.

Chen, W.H., Yang, W.B., Yuan, C.S., Yang, J.C. and Zhao, Q.L. (2013). Influences of aeration and biological treatment on the fates of aromatic vocs in wastewater treatment processes. Aerosol Air Qual. Res. 13: 225236.

Chou, M.S. and Wang, C.H. (2007). Treatment of ammonia in air stream by biotrickling filter. Aerosol Air Qual. Res. 7: 17-32.
Dehghani, M., Sorooshian, A., Ghorbani, M., Fazlzadeh, M., Miri, M., Badiee, P., Parvizi, A., Ansari, M., Baghani, A.N. and Delikhoon, M. (2018). Seasonal variation in culturable bioaerosols in a wastewater treatment plant. Aerosol Air Qual. Res. 18: 2826-2839.

Fang, G.C., Huang, Y.L. and Huang, J.H. (2010). Study of atmospheric metallic elements pollution in Asia during 2000-2007. J. Hazard. Mater. 180: 115-121.

Hamoda, M.F. (2006). Air pollutants emissions from waste treatment and disposal facilities. J. Environ. Sci. Health A 41: 77-85.

Haney, J.T., Phillips, T., Sielken, R.L. and Valdez-Flores, C. (2015). Development of an inhalation unit risk factor for isoprene. Regul. Toxicol. Pharm. 73: 712-725.

Haynes, E.N., Ryan, P., Chen, A., Brown, D., Roda, S., Kuhnell, P., Wittberg, D., Terrell, M. and Reponen, T. (2012). Assessment of personal exposure to manganese in children living near a ferromanganese refinery. Sci. Total Environ. 427-428: 19-25.

He, Z., Li, G., Chen, J., Huang, Y., An, T. and Zhang, C. (2015). Pollution characteristics and health risk assessment of volatile organic compounds emitted from different plastic solid waste recycling workshops. Environ. Int. 77: 85-94.

Ho, K.F., Lee, S.C., Guo, H. and Tsai, W.Y. (2004). Seasonal and diurnal variations of volatile organic compounds (VOCs) in the atmosphere of Hong Kong. 
Sci. Total Environ. 322: 155-166.

Hua, X., Wu, Y.J., Zhang, X., Cheng, S., Wang, X., Chu, J. and Huang, Q. (2018). Analysis on ambient volatile organic compounds and their human gene targets. Aerosol Air Qual. Res. 18: 2654-2665.

Huang, C.H., Chen, K.S. and Wang, H.K. (2012). Measurements and PCA/APCS analyses of volatile organic compounds in Kaohsiung municipal sewer systems, Southern Taiwan. Aerosol Air Qual. Res. 12: 1315-1326.

Li, Y., Yang, L., Meng, Q., Qiu, X. and Feng, Y. (2013). Emission characteristics of microbial aerosols in a municipal sewage treatment plant in Xi'An, China. Aerosol Air Qual. Res. 13: 343-349.

Kumar, P. and Yadav, S. (2016). Seasonal variations in water soluble inorganic ions, $\mathrm{OC}$ and $\mathrm{EC}$ in $\mathrm{PM}_{10}$ and $\mathrm{PM}_{>10}$ aerosols over Delhi: Influence of sources and meteorological factors. Aerosol Air Qual. Res. 16: 1165-1178.

Lee, J.A., Johnson, J.C., Reynolds, S.J., Thorne, P.S. and O'Shaughnessy, P.T. (2007). Indoor and outdoor air quality assessment of four wastewater treatment plants. J. Occup. Environ. Hyg. 3: 36-43.

Li, Y., Yang, L., Meng, Q., Qiu, X. and Feng, Y. (2013). Emission characteristics of microbial aerosols in a municipal sewage treatment plant in Xi'An, China. Aerosol Air Qual. Res. 13: 343-349.

Liu, X. and Wang, R. (2017). An innovative approach to oxidative removal of hydrogen sulfide using the solution of peroxo heteropolyacid. Aerosol Air Qual. Res. 17: 1341-1346.

McCarthy, M.C., O’Brien, T.E., Charrier, J.G. and Hafner, H.R. (2009). Characterization of the chronic risk and hazard of hazardous air pollutants in the United States using ambient monitoring data. Environ. Health Perspect. 117: 790-796.

Nelson, P.F. and Quigley, S.M. (1984). The hydrocarbon composition of exhaust emitted from gasoline fuelled vehicles. Atmos. Environ. 18: 79-87.

Ou-Yang, C.F., Chang, C.C., Wang, J.L., Shimada, K., Hatakeyama, S., Kato, S., Chiu, J.Y., Sheu, G.R. and Lin, N.H. (2017). Characteristics of summertime volatile organic compounds in the lower free troposphere: Background measurements at Mt. Fuji. Aerosol Air Qual. Res. 17: 3037-3051.

Rai, N.K. (2018). Emission of various contaminants into ambient air from wastewater treatment plant. Int. Res. J. Environ. Sci. 7: 74-77.

Ramírez, N., Cuadras, A., Rovira, E., Borrull, F. and Marcé, R.M. (2012). Chronic risk assessment of exposure to volatile organic compounds in the atmosphere near the largest mediterranean industrial site. Environ. Int. 39: 200-209.

Sexton, K., Linder, S.H., Marko, D., Bethel, H. and Lupo, P.J. (2007). Comparative assessment of air pollutionrelated health risks in Houston. Environ. Health Perspect. 115:1388-1393.

Singh, D., Kumar, A., Kumar, K., Singh, B., Mina, U., Singh, B.B. and Jain, V.K. (2016). Statistical modeling of $\mathrm{O}_{3}, \mathrm{NO}_{\mathrm{x}}, \mathrm{CO}, \mathrm{PM}_{2.5}$, VOCs and noise levels in commercial complex and associated health risk assessment in an academic institution. Sci. Total Environ. 572: 586594.

Sofuoglu, S.C., Aslan, G., Inal, F. and Sofuoglu, A. (2011). An assessment of indoor air concentrations and health risks of volatile organic compounds in three primary schools. Int. J. Hyg. Environ. Health 214: 36-46.

TCG (Taiwan City Government) (2017). Sewerage Systems Office, Public Works Department, Taiwan City Government, Taiwan.

Upadhyay, N., Sun, Q., Allen, J.O., Westerhoff, P. and Herckes, P. (2012). Characterization of aerosol emissions from wastewater aeration basins. J. Air Waste Manage. Assoc. 63: 20-26.

U.S. EPA (1989). Risk assessment guidance for superfund. Volume I. Human Health Evaluation Manual ((Part A)), Environmental Protection Agency, Washington, D.C., USA.

U.S. EPA (2017). IRIS, Integrated risk information system, http://www.epa.gov/iris, Environmental Protection Agency, Washington, D.C., USA.

Vijayan, G., Saravanane, R. and Sundararajan, T. (2017). Carbon footprint analyses of wastewater treatment systems in Puducherry. Comput. Water Energy Environ. Eng. 6: 281-303.

Wang, G., Cheng, S., Wei, W., Zhou, Y., Yao, S. and Zhang, H. (2016a). Characteristics and source apportionment of VOCs in the suburban area of Beijing, China. Atmos. Pollut. Res. 7: 711-724.

Wang, Y.C., Lin, C., Lin, Y.K., Wang, Y.F., Weng, W.H. and Kuo, Y.M. (2016b). Characteristics and determinants of ambient volatile organic compounds in primary schools. Environ. Sci. Processes Impacts 18: 1458-1468.

Widiana, D.R., Tsai, J.H., Wang, Y.F., You, S.J. and Yang, H.H. (2017). Source apportionment of air pollution and characteristics of volatile organic compounds in a municipal wastewater treatment plant, North Taiwan. Aerosol Air Qual. Res. 17: 2878-2890.

Wu, S., Deng, F., Hao, Y., Shima, M., Wang, X., Zheng, C., Wei, H., Lv, H., Lu, X., Huang, J., Qin, Y. and Guo, X. (2013). Chemical constituents of fine particulate air pollution and pulmonary function in healthy adults: The Healthy Volunteer Natural Relocation study. J. Hazard. Mater. 260: 183-191.

Zhang, J., Sun, Y., Wu, F., Sun, J. and Wang, Y. (2014). The characteristics, seasonal variation and source apportionment of VOCs at Gongga Mountain, China. Atmos. Environ. 88: 297-305.

Zhang, J., Wei, E., Wu, L., Fang, X., Li, F., Yang, Z., Wang, T. and Mao, H. (2018). Elemental composition and health risk assessment of $\mathrm{PM}_{10}$ and $\mathrm{PM}_{2.5}$ in the roadside microenvironment in Tianjin, China. Aerosol Air Qual. Res. 18: 1817-1827

Received for review, November 2, 2018 Revised, January 5, 2019 Accepted, January 15, 2019 